\title{
Harnessing the Potential of Community Resources as an Antidote to Poor Academic Performance in Physics
}

\author{
Aina, Jacob Kola, Philip Yamma Joseph \\ Physics Department College of Education (T) Lafiagi Kwara State, Nigeria
}

\begin{abstract}
The paper reviewed students' academic performance in physics caused by failure of classroom to meet up with teaching and learning process due to students and teachers attitude; professional and pedagogical factors. The paper discussed the full potentials available in our communities that can be used to teach physics for students' better understanding. Some problems like school location, class size and others were seen as problems to the use of community resources. Some recommendations were suggested at the end of the review one of such recommendations was that government should develop rural communities to assist youth education. Keywords: classroom, community, resources, teaching and learning.
\end{abstract}

\section{Introduction}

There is no doubt that students' academic performance in physics in Nigerian schools and some other countries of the world is poor. The reasons for this are many based on research studies. Some said physics is abstract (Adeyemo, 2010); some believed it is mathematical (Aina,2013); some blamed teachers for this poor performances; Aiyelabegan (2003) argued that lack of facilities like laboratories causes students' poor performance in physics, some believed students' attitudes and low interest to learning equally contributed to poor performance in physics (Aina, 2013).

Scholars have carried out many researches in attempt to find solution to students' poor performance in physics; yet there seem to be no improvement. It is on this background that the paper is reviewing the potential of community resources as a possible solution to this problem.

Physics learnt in classrooms that cannot be applied outside the classroom is useless; the beauty of any science is being able to apply its knowledge in real life situation outside the school. Lee (2012) advocated for authentic science learning that would be relevant outside classroom and to individuals. Students will not be able to perform well if what they learnt in classrooms cannot be connected to experiences outside the classroom; this is an indication that conventional classroom experience is failing. Studies have shown that the outdoor setting of an educational programme can have a valuable formative influence on the students (Drissner, Haase, Rinderknecht and Hille, 2013)

The conventional classroom situation has failed to achieve its purpose due to many reasons that this paper will fully discussed. The failure of classroom experience to produce desired results makes it imperative to look for an alternative using community resources. Before the advent of western education, community education has been in operation in Africa. In another language community education is called informal education; it has been a powerful tool to educate people because it gives people knowledge and skill (Orimogunje and Olatunji, 2010).

\section{Conventional classroom situation}

The conventional classroom experience has failed to achieve its full purpose in the lives of learners today because of the under mentioned reasons.

\section{Attitude}

Both student and teacher are not showing good attitude towards teaching and learning again. Students are not showing positive attitude towards learning anymore perhaps due to high rate of unemployment among young school leavers in the country. It could also be due to lack of motivation to learning from either parents or government in providing learning materials for these students.

Motivation is very important to students' learning; according to Christiana (2009), motivation has high positive correlation in the academic performance of students. The best motivation any student can have towards learning comes from parents; where student lack this parental motivation it always reflect in their academic performance. Parent has a great influence on students' education that is why Wentzel (1998) said, perceived support from parents was related to interest in school by way of negative relations with emotional distress.

Teachers on the other hand are not well motivated through their take home allowances and other incentives; the income of many teachers could not feed him and his family. In view of this he needs to take to other business inimical to his primary assignment of teaching. Many physics teachers have lost interest in teaching; they don't 
have time for their students. The summary is that their attitude to classroom teaching is bad and the resultant effect is on the students.

This contributed greatly to the failure of classroom in achieving its original purpose of equipping students with adequate knowledge needed to pass physics examination. Unless something positive is done to compliment classroom process of learning, students' performance may continue to decline.

\section{Professional}

Classroom of many schools today are full of unqualified teachers; many are not academically or professionally qualified and in some cases both. There was a case where a state governor lamented the presence of unqualified teachers in classroom as observed by Ogundele and Opara (2013). It is not unlikely to find an engineer teaching physics in some schools today; this is wrong, an engineer is not a professional teacher. $\mathrm{He}$ may know calculations, some concepts and principle in physics but he does not know anything about classroom process, therefore he cannot teach well. This is the same as asking a biology teacher to take the position of a medical doctor in the hospital; the risk will be incalculable.

\section{Pedagogical}

The art of teaching is very important; many of our classrooms today are full of teachers who only believed in covering physics syllabus not minding if students understand or not. Many things are involved in the teaching and learning process that both students and the teachers should know or else they all labour in vain because students will not pass as expected. Physics teacher should know the nature of learning; methods of teaching, student assessments and classroom management.

Physics teacher should not only be concerned with the subject but should consider his/her student; their feeling and emotion during teaching; the right type of teaching method to be used for a particular topic; when to assess the students and the type of assessment. Classroom management is very important in teaching all these are what many physics teachers' lacks that leads to students' poor performance.

\section{Concept of community education}

This is an informal education that goes on in the community without necessarily been in four wall of classroom. This was the African type of education before the advent of western education. This type of education helps people to respond to the needs and discover their roots so that they can reach out successfully for a new balance between tradition and innovation (Orimogunje and Olatunji, 2010).

Through this education physics is taught and learnt without going to any special building that we called classroom today. They tell stories, observed the universe, study time, do measurement, they hypothesized, analyzed, collect data all these are what we called science processes today (Aina, 2010).

Without written physics textbooks they adequately explored their immediate environment for learning; unless we go back to this method of exploring community resources students' performance may not be better. We should stop depending on textbooks rather we should make textbooks compliment what students can see in the community. Let students explore his/her community for his/her physics learning, after all some of the laws we used in physics today were not discovered in classroom. Achimedes discovered law of floatation in his bathroom not in the classroom; gravitational and relativity laws were not discovered in classroom. There are many available resources in our community that makes physics very interesting; let us take physics out of four wall of classroom for better results.

\section{The community resources}

These are resources available in a student's community that can be used for his/ her learning. There are many of these resources depending on the school location; however, the following would be discussed in this paper:

- Industrial resources

- Resources from government ministry

- Parks/workshops

- Homes

\section{Industrial resources}

Resources abound in factories and companies' that physics teachers could use for physics instructions. The need for this is that it gives first hand information to students about the learning concepts. For instance, learning electric motor or dynamo in physics would be best appreciated by students if they see it in operation; they can see various parts of the motor either for alternating or direct current then ask questions. Learning this in classroom may not be able to give good comprehension and long term memory. Taking students to the factories where they can see it is very important, it makes the teaching and learning practical. 
In a community where there is no factory, teacher can still get materials in the same community to make improvisation because Daniel (2001) stressed that, at this era of Information and Communication Technology [ICT] teachers must be able to make use of available local resources in his/her environment to produce instructional and learning materials in schools.

\section{Government ministry}

Many experts are available in government ministries all over the nation who can serve as resource person for teaching of physics. For example, there are equipments and experts in ministries like ministry of health, ministry of work, ministry of agriculture etc in Nigeria which can be used to teach physics. Production and uses of X-ray is a common topic in physics; there is nothing bad in taking students into the ministry of health where students can see X-ray in operation and be able to ask questions from the radiographer who is an expert. This will assist the student not only seeing the x-ray machine but have first hand information from the expert; learning of this type will be more permanent in student brain. Most teachers teaching some of these topics have not come across the machine and equipment they also learnt it through textbooks; students of this day are more curious in seeing what they are learning.

Physics teachers gives examples of simple machines like pulley, screw, jack etc but operating most of this machine is only done referring students to textbooks. Students will best appreciate the operation of these machines if we can visit ministry of work and allow these students to see the machines as applied in the modern day technology.

Most students comes from poor family where no one has a car and possibly has never seen any type of jack before; taking such student to a mechanic workshop to see different type of jacks and teach him concepts like, load, effort, fulcrum, mechanical advantage will be practical. Such learning will be permanent and remove the notion of abstractness in physics.

\section{Artisan/Road side workers}

Communities in Nigeria are full of artisans, road side vulcanizers, automobile mechanics, welders, radio repairer etc; physics students could be taking to these people to learn so many things. In thermodynamics, we teach diesel and gasoline engines and their operation but many students have never seen any of these engines before except seeing the car on the road. Many schools cannot afford buying these engines for students' learning; therefore the best option is taking the students to the nearest automobile mechanic workshop where they could see these engines and be able to ask questions from the experts.

We teach Pressure and Boyle's laws in physics; how many students can apply these laws in real life situation? Take these students to a vulcanizer workshop and let them see how they pump tyre and what happen when a tyre is deflated; all these are practical teaching that can make learning permanent.

Teachers should ensure he/she explains to the students if there is misconception of any concept during the excursion when they are back to class. This is because names given to some of the equipment by these so called experts might be different from the scientific names. For example, resistor, capacitor, transistor etc are often called different names by some of these artisans probably because of their level of education.

\section{Homes}

Home is very important to learning of science because many students feel more relax to learn best under their parent as asserted by Crowley et al. (2001) that Children engaged in shared scientific thinking with their parents had greater opportunity to learn than children engaged in scientific thinking with peers or by themselves.

However, such home environment must be conducive to learning as opined by Lee (2012) that provision of conducive environment for students learning is very important in science; this is the responsibility of parents at home when students are outside the four walls of classroom.

There are many physics concepts that can be learn at home through the help of parents; such learning will be more practical and permanent. For instance heat transfer through conduction, convection and radiation can be taught easily by every parent at home. Everybody knows if you leave a spoon for a long period inside a cup of hot tea will make the handle of the spoon become hot; though the handle was not directly in contact with the hot tea. Parents can as a matter of home training tell a child not to allow spoon stay in a hot tea cup and explain the reason to him/her. Kitchen is always warmer than the sitting room because of radiation from the oven or stove; students need not to get to physics class before knowing this.

Africa is rich with superstitious beliefs that aids scientific enquiry. Aina (2012) posited that many superstitious beliefs in Africa are to teach certain moral value which when critically observed is scientific. Telling children about these superstitious beliefs at home will lead to learning by inquiry. For instance, some communities in Nigeria believed that rainbow is a result of a reptile bathing in a river; this has been scientifically proved wrong that rainbow is due to refraction and total internal reflection. 
Problems of community resources

Community resource is good for teaching physics but the following problems may hinder its full benefits:

\section{School location}

Schools that are located in the rural areas may have problem of benefitting much in the use of community resources. Many rural areas have neither industry nor the presence of any government ministry; students may have to travel to towns and cities where all these are available.

\section{Low education}

Many of the artisans and road side technicians are illiterate or have low education background that may hinder them from communicating well with the students. It is true that most of them are expert but communication problem may arise because of language barrier.

Class size

Students' population in most secondary schools is large that it becomes very difficult to carry such population for an excursion at once, especially into factories. If students' number are too many it may be very difficult to get the attention of all of them except we have a moderate number at a time.

Lack of fund

Extra money is needed for student excursion outside school premises for transportation and other logistic.

\section{Conclusion and recommendations}

The paper clearly adduced various reasons for the failure of classroom to achieve its purpose in teaching and learning of physics such as attitude of both students and teachers; professional and pedagogical factors. There are many available opportunities for students to learn physics through industries, government ministries, artisan, road side technicians and homes; anything learns here will be permanently retained in students' memory. It is therefore very important to make adequate use of community resources for physics teaching and learning; it will improve students' performance as they will be able to apply their classroom experience to real life situation outside the school.

The following recommendations are hereby suggested based on this review:

- Community physics learning must be made compulsory for every school; this will allow every physics teacher to make adequate provision for students to always go on excursion

- Government should make special fund available for community physics learning

- Parents should be more involved in their children learning; knowing that they are the first physics teacher of their children

- Physics teachers should always be conscious of application of physics to real life situations outside classroom and their teaching should be tailored towards this

- Government should ensure that rural communities are developed by citing industries in small towns and villages to assist youth education.

- Physics teachers should always attend seminars, conferences and workshops on the importance of community resources to students' learning

\section{References}

[1]. Adeyemo, S.A. (2010). Teaching/ learning physics in Nigerian secondary school: The curriculum transformation, issues, problems and prospects. International Journal of Educational Research and Technology, 1(1), 99-111

[2]. Aina, J.K. (2010). The Prospective Physics Teacher. Basic Concepts in Science 2, Ilorin, Nigeria: The author

[3]. Aina, J.K (2012). Scientific explanations of some superstitious beliefs in Nigeria. Retrieved from

"http://www.articlesbase.com/science-articles/scientific-explanations-of-some-superstitious-beliefs-in-nigeria-5869186.html

[4]. Aina, J.K.(2013). Subject Area Specialization-Combination Correlation in Colleges of Education: Effect on Students' Achievement in Physics. Open Journal of Education, 1(3), 113-116. DOI: 10.12966/oje.06.06.2013

[5]. Aiyelabegan, T,A (2003). Effect of physics practical on students' academic performance in senior school certificate examination in Kwara state. Lafiagi Journal of Science Education. 1\&2, 34

[6]. Christiana, O (2009). Influence of motivation on students' academic performance. Medwell Journals, 4(1), 30-36

[7]. Crowley, K. et al (2001). Shared scientific thinking in everyday parent-child activity Science Education, 85(6), 712-732

[8]. Daniel, I.Y (2001, September). Improvisation and use of instructional materials in science teaching, A paper presented at NCCE/UNESCO Workshop For train the trainers' workshop. Kotangora.

[9]. Lee, A.N. (2012). Development of a parent's guide for Singapore primary science: Empowering parents as facilitators of their children's learning outside formal classroom. Asia-pacific Forum on Science Learning and Teaching, 13(2), 1-27

[10]. Ogundele, K. and,. Opara, E.(2013, September 19). Aliyu blast Wike over comments on education. The Punch, Retrieved www.punchng.cm/

[11]. Orimogunje,O.P and Olatunji,O.(2010). Community education as a catalyst for political development in Nigeria: A case study of Ilesa East and West local government areas of Osun State. South West Journal of Teacher Education, 3(1), 365-376

[12]. Wentzel, K.R (1998). Social relationships and motivation in middle school: The role of parents, teachers and peers. Journal of Educational Psychology, 90(2), 202-209 